\title{
ПРОФЕСІЙНІ ЯКОСТІ СТУДЕНТІВ В УМОВАХ КРЕДИТНО-МОДУЛЬНОЇ СИСТЕМИ
}

І. В. Шлімкевич

ДВНЗ “Івано-Франківськийнаціональниймедичнийуніверситет”

\section{PROFESSIONAL QUALITY OF STUDENS UNDER CONDITION OF CREDIT-MODULAR SYSTEM}

\author{
SHEI "Ivano-Frankivsk National Medical University”
}

\author{
I. V. Shlimkevych
}

\begin{abstract}
Практична підготовка студентів-лікарів є обов'язковим компонентом освітньо-професійної програми для здобуття кваліфікаційного рівня і має на меті набуття ними професійних навичок та вмінь. Сприяє формуванню та поглибленню клінічного мислення майбутнього медика, тобто вмінню комплексно оцінити різноманіття симптоматики клінічної картини та миттєво приймати рішення.
\end{abstract}

Practical training doctors is a compulsory component of educational and vocational programs to obtain qualification and is intended acquisition of professional skills. Promote the formation and strengthening of clinical medical thinking of the future, that is, the ability to comprehensively assess the diversity of symptoms and the clinical picture instantly make decisions.

Вступ. Реформування вищої медичної освіти після приєднання України до Болонського процесу спричинило зміщення акцентів у підготовці майбутніх фахівців у бік використання інноваційних технологій, спрямованих на якісний освітній результат, що дає можливість підготовки висококваліфікованих кадрів, які будуть конкурентоспроможними на ринку праці, а саме здатні до компетентної, відповідальної й ефективної діяльності за своєю спеціальністю [1].

В Україні чітко визначено орієнтири на входження в освітній та науковий простір Свропи, здійснюється модернізація освітньої діяльності в контексті Болонського процесу. Перехід до нової моделі організації навчального процесу потребує від професорськовикладацького складу вищих медичних навчальних закладів оволодіння новою системою психологопедагогічних та методичних вмінь. Актуальним завданням сучасної медичної освіти $€$ покращення якості підготовки висококваліфікованих спеціалістів в аспекті майбутньої практичної діяльності [3].

Основна частина. Основним завданням розвитку медичної освіти в Україні $€$ необхідність підготовки висококваліфікованого, конкурентоспроможного лікаря, здатного гнучко переорієнтовувати свою діяльність у зв'язку із потребами сфери медицини. Це ставить перед системою вищої медичної освіти

(C) І. В. Шлімкевич завдання вдосконалення процесу професійної підготовки майбутніх лікарів [5].

Формування висококваліфікованого фахівця медика на до- і післядипломному рівнях системи охорони здоров'я неможливо без оволодіння ним певного професійного рівня правових знань, в тому числі прав людини у сфері охорони здоров'я. Підвищення рівня правових знань медичних працівників, їх правової свідомості та правової культури потребують системного та повсякденного, професійно організованого правового виховання, оволодіння знаннями та практичними навичками [8].

Практична підготовка студентів-лікарів є обов'язковим компонентом освітньо-професійної програми для здобуття кваліфікаційного рівня і має на меті набуття ними професійних навичок та вмінь [10]. Проблема професіоналізму в сучасній медицині досі не вичерпна, а підготовка майбутнього спеціаліста має грунтуватися передусім на здобуванні теоретичних знань та оволодінні практичними навичками ще на додипломному етапі навчання [4]. На сьогодні теоретична підготовка стає якісною завдяки електронним навчальним платформам, в той час як вдосконалення практичної підготовки фахівців на додипломному етапі залишається актуальним питанням [2].

Практичні навички та вміння займають особливе, базове місце в системі професійної освіти, тому вони складають основний етап практичного заняття. Про- 
фесійні навички є відносно простими професійними діями і відносяться до нижчої сходинки III рівня засвоєння. Основним методом формування навичок $\epsilon$ практичний тренінг: систематичне повторювання певних професійних дій за заданим алгоритмом 3 метою досягнення стадії автоматизованого виконання. Головним критерієм при визнанні рівня професійної підготовки фахівця є його вміння: здатність оперувати складною системою теоретичних знань і практичних навичоку вирішені складних, нетипових, нестандартних професійних задач.

Значним змістом наповнена педагогічна толерантність, філософія якої базується на визнанні за кожною людиною права мати власні погляди, принципи, ставлення до навколишнього світу. Звичайно, що виховна цінність заняття залежить від культури викладача, від його ставлення до студентів, від його авторитету, від уміння організувати творче та діяльне спілкування на занятті, від уміння захопити, зацікавити, від бажання, здатності й уміння бути душею 3 вихованцями [7]. Особливо актуальним $є$ принцип толерантності у медичних закладах, де кожен працівник повинен бути прикладом для наслідування i тому зобов'язаний проявляти високий ступінь щиросердечності, терплячості та поваги до студентів. Вагоме значення у здобутті практичних навичок студентами має досвід та педагогічна майстерність викладача. Для ознайомлення студентів 3 новою клінічною навичкою викладачі використовують відеоматеріали, анатомічні муляжі, ігрову форму заняття та демонструють маніпуляції на реальному пацієнті. Засвоювання практичних навичок полягає в усвідомленні та запам'ятовуванні професійних алгоритмів їх виконання, що опубліковані в методичних вказівках для студентів [7].

Відповідаючи на нові виклики життя, ми говоримо не про навчання, а про формування спеціаліста як професіонала, творця, організатора, людини з демократичним, високогуманним, державницьким світоглядом [9]. 14 складових формування особистості молодого лікаря: гуманність, професійність, працьовитість, відповідальність, організованість, управлінські якості, доброзичливість, комунікабельність, ініціативність, винахідливість, привабливість, інтелігентність, демократичність, переконливість.

Одним із важливих напрямків євроінтеграції нашої країни є сфера вищої освіти [6]. 3 вересня 2005 року у вищих навчальних закладах нашої держави навчання студентів здійснюється згідно з основними положеннями Болонської декларації із використанням принципів кредитно-модульної системи [7]. Позитивними наслідками введення кредитно-модульної системи повинно стати наближення рівня вищої освіти в Україні до європейського і реалізація ідеї: “"Bringing students to Europe, bringing Europe to all students" "Відкрити студентів для Європи, відкрити Європу для всіх студентів" [4]. Впровадження європейської системи освіти передбачає підвищення активності студентів, зростання вимог до якості викладання дисциплін, стимулювання і удосконалення процесів моніторингу за якістю освіти і оцінки засвоєння професійних якостей студентами освітньо-професійних програм, створення сучасного інформаційного i навчально-методичного забезпечення викладання кожної дисципліни, модернізацію матеріальнотехнічної бази [2].

Висновок. В результаті випускник медичного закладу відчуває себе впевненим на ринку праці, вміє адаптуватися до соціальних змін і криз у суспільстві, $€$ психологічно стійким, розвиває здатність до самореалізації та формування творчої особистості. Враховуючи, що правові та етичні гарантії, захист прав людини є невід'ємними компонентами якості - це також сприятиме поліпшенню надання якісної медичної допомоги. Практична підготовка сприяє формуванню та поглибленню клінічного мислення майбутнього медика, тобто вмінню комплексно оцінити різноманіття симптоматики клінічної картини та миттєво приймати рішення. Тому доцільним вважаємо удосконалення роботи на кафедрах педіатричного профілю з метою максимальної оптимізації співпраці із студентами. Для цього, на нашу думку, необхідно: зберегти практичну спрямованість викладання, підвищити мотивацію студентів до отримання знань, а не оцінок, шляхом посилення проблемно-орієнтованих підходів по відношенню до матеріалу, поліпшити якість самостійної роботи студентів шляхом створення структурованих методичних вказівок для підготовки до занять та розробки нових форм та методів самостійної роботи, проводити максимальне заохочення всіх форм індивідуальної (творчої) роботи студентів у межах вивчення дисципліни та підвищення уваги щодо формування змістовних зв'язків із адекватною формою міждисциплінарної інтеграції. 


\section{Списоклітератури}

1. Завдання вищої медичної освіти в контексті реформування галузі / Р. О. Моісеєнко, В. В. Вороненко, І. І. Фещенко [та ін.] // Ваше здоров’я. -2011. -№ 31. - С. 10-28.

2. Інтеграція навчального процесу-основа ефективності кредитно-модульної системи навчання / П. О. Неруш, О. Г. Родинський, О.В.Мозгунов [та ін.] // Медична освіта. 2008. - №4. - С. 16-17.

3. Медична освіта у світі та в Україні / [ Ю.В.Поляченко, В. Г. Передерій, О. П. Волосовець та ін.]. -К., 2005. - 383 с.

4. Москаленко В. Ф. Медична освіта України та болонський процес: реальність та шляхи приєднання до європейського освітнього і наукового простору / В. Ф. Москаленко // Журнал АМН України. -2005. - Т. 11, № 1.-С. 36- 44.

5. Оптимізація навчального процесу у підготовці лікарівінтернів-стоматологів. (Повідомлення 4.) / С. В. Косенко, М. М. Рожко, 3. Т. Костишин [та ін.] // Галицький лікарський вісник. -2012. - Т.19, № 1.-С. 117-118.
6. Основні засади розвитку вищої освіти України в контексті Болонського процесу (документи і матеріали 20032004 рр.) / за ред. В. Г. Кременя. - К.; Тернопіль, 2004. - 147 с.

7. Притика Ю. Проблеми впровадження стандартів Болонського процесу / Ю. Притика // Правовий тиждень. 2009. - № 21 (147). - С. 6-7.

8. Суліма Є. Невідкладні завдання системи вищої освіти на новому етапі Болонського процесу / Є. Суліма // Вища школа. -2010. - № 11.- С. 5-13.

9. Туркіна М. В. Сутність поняття самостійної навчально-пізнавальної діяльності студентів у психологічній та педагогічній літературі / М. В. Туркіна // Вісник ЛНУ імені Тараса Шевченка. -2011. -№ 5 (216). -С. 110-114.

10. Шамова Т. И. Управление образовательными системами : учеб. пособие для вузов по специальностям : 031000 "Педагогика и психология", 033400 "Педагогика" / Т. И. Шамова, Т. М. Давыденко, Г. Н. Шибанова // Междунар. акад. наук пед. образования. - М. : ACADEMIA, 2008. -384 c. 